\title{
Morphological analysis of frontier villages in Cyprus
}

\author{
Erincik Edgü, Nevter ${ }^{1}$ Zafer Cömert $^{2}$, Nezire Özgece ${ }^{3}$ \\ ${ }^{1}$ Department of Architecture. Düzce University. Düzce. Turkey \\ ${ }^{2}$ Department of Architecture. Eastern Mediterranean University. Famagusta. Northern Cyprus \\ ${ }^{3}$ Department of Architecture. Cyprus International University. Nicosia. Northern Cyprus \\ E-mail: erincik@gmail.com,nzafer@gmail.com,nezireozgece@gmail.com
}

\begin{abstract}
Borders may be built for security reasons however; they also demarcate administrative, economic, socio-cultural, ethnic or religious divergence. Borders change the destinies of the societies at both sides because they affect the process of urban development and delimit the economic and socio-cultural interactions. Cyprus has been experiencing an interrupted continuity along the border, i.e. green line, under the rule of UN that divides north from the south. In this regard, the aim of the study is to figure out how the de facto borders affect the configuration of villages upon their existing position. As a part of an ongoing research which investigates all eleven frontier villages and towns located along the border line, this paper only focuses on the morphological and syntactic comparison of four frontier villages. Within this context, initial exploration is about the village morphologies by means of Morphological Regions based on the evolutionary insights of Conzen (2004) and Whitehand (2009). Additionally, considering shifted centrality and transformed social gathering spaces, research discusses the applicability of the comparative analyses of syntactic and morphological methods in order to reveal the characteristics of the frontier villages. The preliminary findings of the research indicate that edge villages located along the green line have a controlled spatial development with dead ends and loop layouts, where the spatial configuration presents an introverted structure. On the other hand, villages divided by the green line, presents a relatively integrated spatial structure developed on both sides of the border, maintaining traditional centrality along with emphasizing forced territoriality.
\end{abstract}

Keywords: Urban morphology, fringe belts, edges, axiality, centrality

\section{Introduction}

Borders may be built for security reasons however; they also demarcate administrative, economic, socio-cultural, ethnic or religious divergence. Borders change the destinies of the societies at both sides because they affect the process of urban development and delimit the economic and socio-cultural interactions.

Since the complete division of the island and separation of Greeks and Turks after 1974 due to unresolved political situation, Cyprus has been experiencing an interrupted continuity. The border named as green line, is controlled by UN and it divides the island into north and south portions. Division of the island was a critical decision in terms of geography, natural resources and social structure, whereas the differences in the socioeconomic status of both sides affected the development and urban improvement as well. In this regard the aim of the study is to figure out how the de facto borders affected the configuration of villages upon their existing position. As a part of an ongoing research which investigates all eleven frontier villages and towns located along the border line, this paper only focuses on the morphological and syntactic comparison of 
two frontier villages. Within this context, initial exploration is about the village morphologies by means of Morphological Regions based on the evolutionary insights of Conzen (2004) and Whitehand (2009). Additionally, considering shifted centrality and transformed social gathering spaces, research discusses the applicability of the comparative analyses of syntactic and morphological methods in order to reveal the reformed characteristics of the frontier villages. The questions arise in minds 'could it be morphological and syntactic analysis can correlate to each other for finding a better reliable outcomes of the development of city

The preliminary findings of the research indicates that edge villages located along the green line have a controlled spatial development with dead ends and loop layouts, where the spatial configuration presents an introverted structure. On the other hand, villages divided by the green line, presents a relatively integrated spatial structure developed on both sides of the border, maintaining traditional centrality along with emphasizing forced territoriality.

\section{Urban Morphology: Historic Geographical Approach}

The study of urban morphology is associated with different views and perspectives. This interdisciplinary characteristic leads to a deeper observation of the origins of urban morphology. As Whitehand (2011) stated that the urban morphology seeks to understand the spatial structure and character of a metropolitan area, city, town or village by examining the patterns of its component parts and the process of their development, morphological studies in urban context are one of the significant methodologies of analysing the physical formation of towns and cities. Additionally, the studies draw the guidelines for urban planning and design that helps to increase the uniqueness and quality of urban environment. One of the aims of morphological studies is help to understand the evolution of built form. Oliveira (2016) defined the study of urban morphology as a way of introducing the element of form in planning processes by removing that element from the realm of arbitrariness. The methodological approach links methodology in planning without disregarding the nonrational aspects of form. This approach makes it possible to discuss the form of towns based on morphological methods.

Urban Morphology Glossary stated that, "The physiognomy of a town or the urban landscape, being the combination of three systematic form complexes, i.e. town plan, building fabric and land use" (Conzen, 1969, p. 131), "the visual appearance of a town" (OED). Many geographers comprehensively examine a town's scenery and its evolution into its modern form (eg. Smailes, 1955). The usual architectural approach tends to view each element of a townscape more as an individual work of artistic merit, and seems to claim that townscaping is an applied art (Cullen, 1961). Sharp, unusually and early for a planner, also makes this point (Sharp, 1968). Probably best defined in non-technical terms as "a wide scenic view of a town or parts of a town, with common characteristics of design" (Johns, 1991, p. 10).

All these aspects have been the subject of geographical investigation (Conzen 1960). Three schools began to work on urban morphological studies: the English school, the Italian school and the French school. In the scope of the English School, MRG Conzen is a pioneer of morphological studies in urban design (Moudon, 1997, p.3). He is one of the founders of urban morphological studies on the geographical level with the historicogeographical methodology at the University of Birmingham, a school that aims to introduce such studies worldwide. Basically, the approach is related to thinking in terms of ground use and functions and to spatial planning.

\section{Townscape Analysis/Morphological Period}

In Conzen's study of the Alnwick (Market town in Britain), he determined how the historical development of a major aspect of urban form could be expressed in great detail cartographically (Conzen 1960). To understand this it is necessary to appreciate how the diverse urban form complexes relate 
to one another (Whitehand, Gu et al. 2011). The means of morphological periods, like the geosphere of which forms a concrete part, can be viewed under three distinct aspects, suggesting three corresponding approaches: to with the morphological, the functional, and historical. As a part of geographical reality, regions are strictly speaking unique spaces, individuals with distinctive personalities. However they show many recurrent similarities in specific aspects, like human individuals, a fact frequently overlooked in discussion on regional geography, through perfectly well known to scholarly, as a distinct from essentially didactic, practitioners in regional study. Thus regional geography is by no means condemned to the barren contemplation of the unique, but awaits the building up of a theory of regions on the basis of their comparative study, producing a typology or typologies of regions (Conzen, 2004). Usually Townscape analysis needs two types of researches which are historico-geographical evidence which are documentary, cartographic and pictorial. Addition to this, filed survey is needed by developing the concepts corresponding to observable phenomena and so build up a theory of townscape.

Conzens' morphological period, namely a phase of social and cultural history creating distinctive material forms in the cultural landscape. He improved evolutionary approach to tracing existing forms back to the underlying formative processes and interpreting them accordingly, would seem to provide the rational method of analysis of urban morphology. Conzen's urban morphological study focuses on the town plan, which represents a town in two dimensions including all important characteristics of urban form his study of Newcastle upon Tyne, England (Conzen, 1981), he described the complete method, called an evolutionary method of plan analysis, which is the town-plan study of sequential time periods. In his town-plan analysis approach, he identifies three fundamental elements of the town plan that can be analyzed over time in an evolutionary fashion: the streets and their street system, the plots and their plot pattern, and the building arrangement within these patterns
(Conzen, 1968). The evolutionary method of plan analysis provides an understanding of the physical development of urban structural elements, resulting from the city's cultural and historical development (factors that strongly influenced its morphological development), which is an objective of the morphological approach. In the study of Burgage cycle in Newcastle, Conzen also uses an evolutionary town plan analysis as a means to understand its physical development over time The retrogressive method of working back from present-day forms is rejected quite simply because a proper understanding of processes cannot be attained from the analysis of relics, even in the case of the town plan, which produces a more complete collection of residual features than the building fabric or the land-use pattern: those parts of the townscape that have been removed are as important to a theory of townscape development as those that have survived.

Conzen has put major emphasis on the importance of townscape for urban development practices and in two of his papers he has formed a map of townscape for Ludlow (Conzen 1975, 1988) Conzen's townscape are closely related to his idea of the townscape as the 'objectivation of the spirit' of a society. According to him (Conzen, 1968), 'the spirit of past and current societies is represented in the historico-geographical character of townscapes, i.e. the genius loci of Christian Norberg-Shultz.

\section{Syntactic Aspects}

Hillier and Leaman (1974) use the term syntax to refer to rules that generate different spatial arrangements, that are assumed to be shaped due to certain cultural considerations affecting social relations. Space syntax on the other hand, is defined as a methodology to represent, quantify and interpret spatial configuration and visual perception of exterior or interior spaces regardless of their scales by means of convex shapes, and axial lines (Hillier et.al, 1987). Among the components of space syntax methodology, integration determines the distance to a convex shape from all 
points within the system. If the real (global) integration value of the shape is high, reaching to this certain shape from any point within the system, is relatively easy and indirect. Relative (local) integration on the other hand, indicates the distance to a convex shape within the system, from its neighbouring shapes. Higher relative integration value means that reaching to surrounding shapes from this certain shape is relatively easy and indirect. On the other hand, if the shape is located somewhere close to the outermost parts of the system, its integration value decreases, leading to an increase in its mean depth value. Connectivity value refers to number of cells directly connected to a shape within the system. If the shape is located somewhere close to the centre of the system, then it means that the shape has many surrounding cells, thus increasing its integration. Connectivity value works parallel to relative integration; one determines the distance to neighboring cells while the other one determines the quantity.

According to Batty's (2001) description in his initial analysis of isovists referring to Benedikt (1979), there is the identification of six geometric measures from which isovist fields could be established: area, perimeter, occlusivity (or length of occluding boundaries within the isovist), variance and skewness of the radial distances around each vantage point, and a measure of compactness called circularity, defined as the ratio of the square of the perimeter to area. Therefore, circularity is not only a measure of how well a space approximates a circle, but is also a measure of the viewpoint's position within the space. For this reason circularity is not only a measure of the shape of a space but also of the centrality of the viewpoint within that space. It is determined by calculating the area of a perfect circle, whose radius is set to the mean radial length of the isovist and then dividing this by the area of the isovist. Batty (2001) defines compactness as the ratio of average to the farthest distance from each vantage point. Compactness value changes between 0 and 1; Indicating that long, narrow, stringy shapes have values closer to 0 , while round, compact, circular shapes have values closer to 1 . The compactness suggest that adding a linear partition creates more depth than adding a compact, L-shaped or U-shaped partition of the same length. This value is important for us to figure out if the diachronic changes in urban form have also affected the public space uses. The circularity and compactness values give us information about spaciousness and visibility potential of the urban form, whereas the compactness value defines the shape of the obstacle within the visual field, the circularity value denotes the easy perception of a space

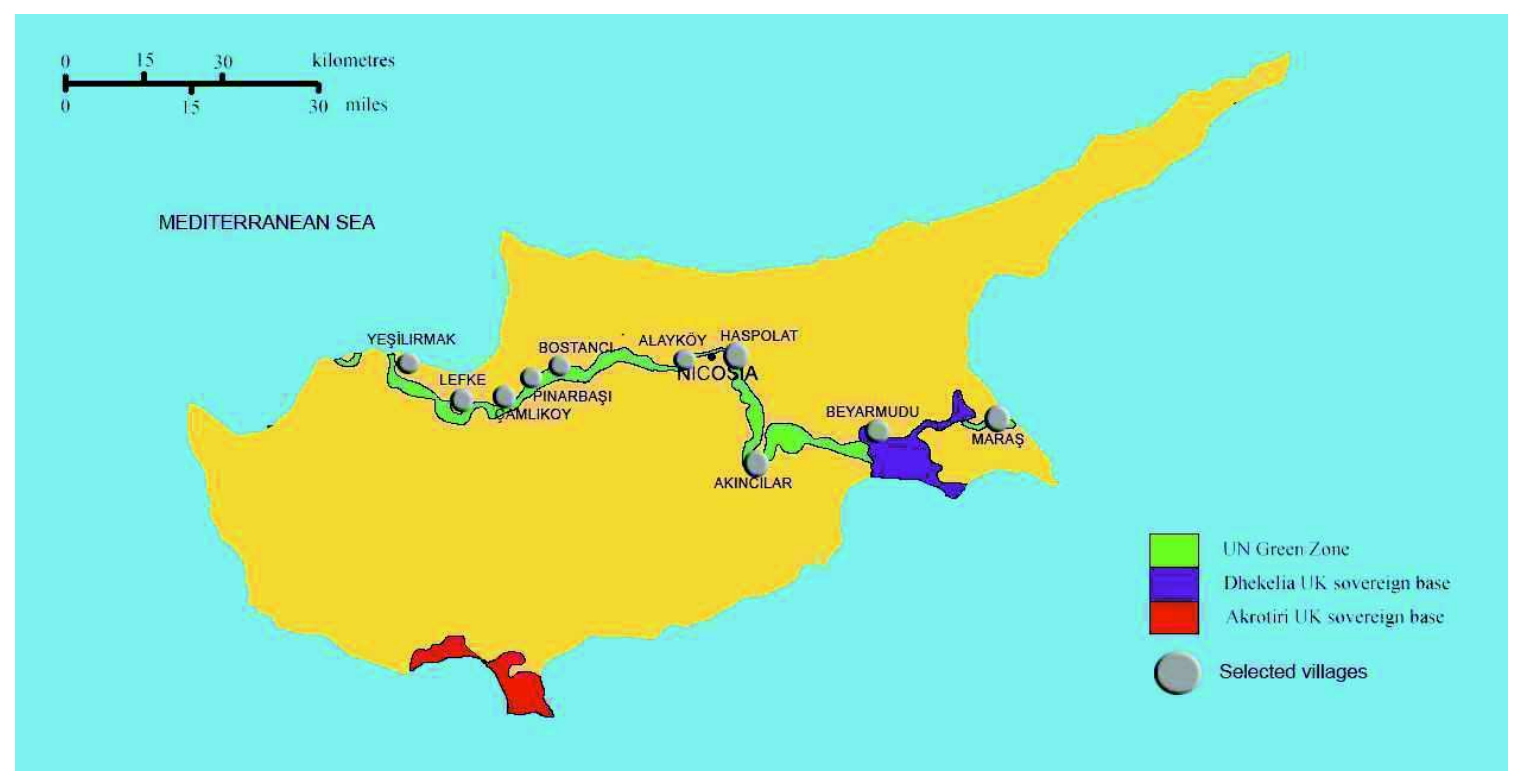

Figure 1

Cyprus green line selected villages. 
at a given instance. Space syntax theory suggests that circle or square like spaces can be observed more quickly than long, narrow or spiky spaces.

\section{Methodology and the Case Study Towns}

The goal of this study is to analyse how the town developed and transformed by further comparison of the topography with street layouts; parcel shapes, sizes, and arrangements; and building characteristics and placement on their parcel. Then by overlaying these characteristics and conditions, a pattern or Genetic Plan Unit becomes visible. The analysis and outcome of this study can help residents and officials plan future development and decide what of the existing urban fabric is valued and worth protecting. On the other hand, changes in the functional uses also give hints about the spontaneous development of patterns whether they maintain their traditional layout or adjust to the new situation.

As mentioned before, this paper only compares the two border towns Beyarmudu and Haspolat out of the ten as seen in Figure 1. The methodology has twofold analyses, one being morphological based on various observations of the towns and other being syntactic based on computational data of various calculations applied to genetic plan units and building pattern of morphological maps. The boundaries used for syntactic grids are adjusted to the commercial, public and residential uses leaving the farm lands and industrial areas out. The University of Michigan software, Syntax 2D is used in for the syntactic data analyses.

Beyarmudu is an enclave carved out by the Turkish Republic of Northern Cyprus. This small town with a dropping population (only 1196 residents in 2011) is fortunate to have crossing checkpoints for passage across the international border. Beyarmudu has two international borders, the one is passing through the southern part of the city where links to Republic of Cyprus. The other border under British rule passes through the western part of the town. The international border is the town's only fixation line but creates a lengthy edge that shapes development on its south and west sides but gives some breathing room on the east. The north side is truncated by the border, which snugs the east side of the only road into town where no border is crossed. Access to the cross border football pitch is permissible from both sides, and farmers' fields have an invisible line drawn across them that does not hinder the plow. The town's industry is primarily agriculture as the surrounding countryside attests. Beyarmudu is not much of a draw for tourists as it is off the main travel routes and does not have any sign.

Haspolat on the other hand, is a suburb village of Nicosia in Cyprus during the British colonial period. After the war, some parts of the town were left in the buffer zone. As of today Haspolat has a population of 4204 inhabitants. According to the Nicosia master plan Haspolat is developed as a light industrial zone. However, the recent development of university campuses nearby, also reinforce the residential uses in the area, towards main connecting roads.

\section{Morphological and syntactic analyses of Towns}

Beyarmudu:

Building Pattern; in Beyarmudu, Figure 2 distinguishes the buildings based on period of construction and architectural styles with precolonial and colonial buildings being grouped as one. The periods were greatly determined based on material, elevation above street level, and setback from street. Some buildings also helped with period placement by displaying buildings dates on their façades.

Buildings built before 1956 code changes were frequently built with no or little setback. For example, those built with adobe, a material mostly used pre-conflict, are typically at grade with 30 percent built at the street edge and 51 percent built within one meter of the street. Analysis shows that more than half of the concrete buildings have setbacks of 3.5 to 4 meters placing their construction after 1956. This aligns with the dating of most concrete construction after the conflict. Despite grouping buildings by overlaying various characteristics, 


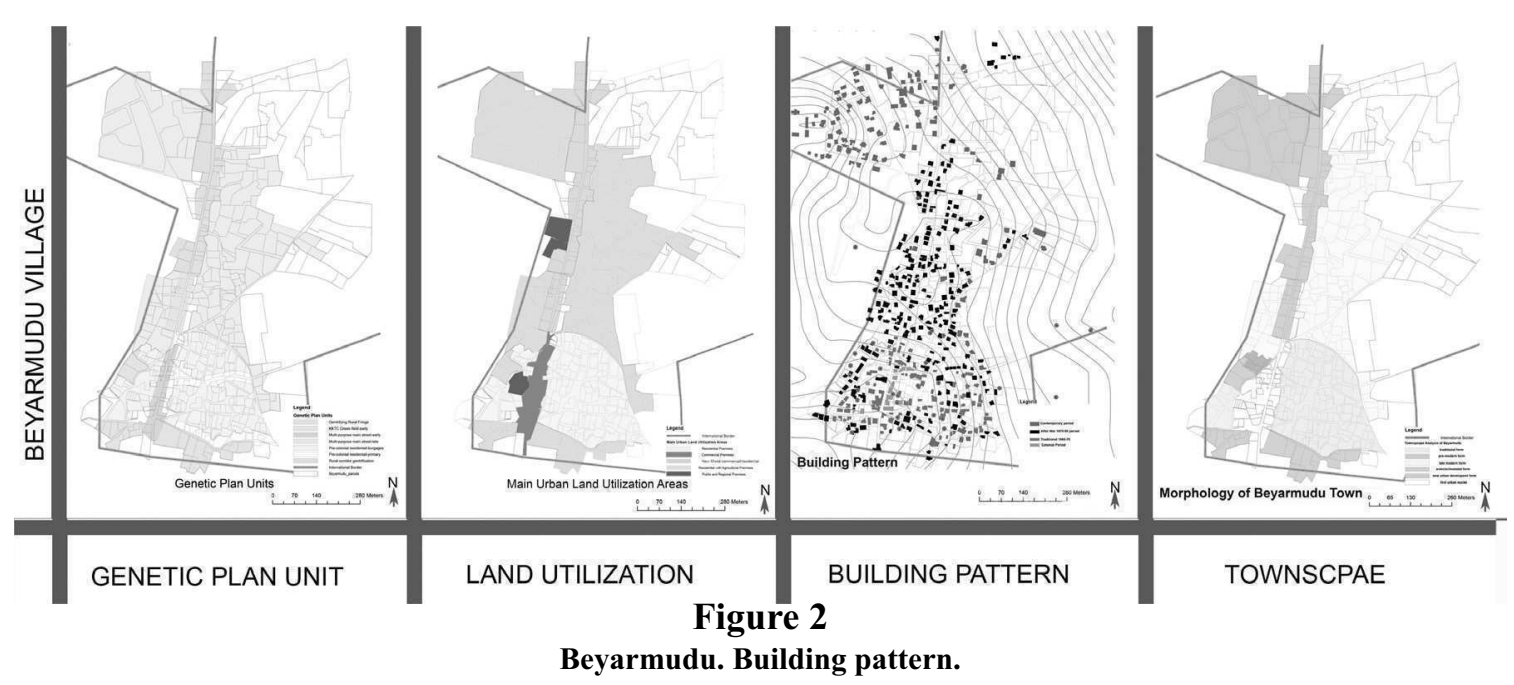

the above pairings and several other attempts do not align in any geographic pattern to suggest Plan Unit. Seemingly, the grouping of materials, elevations, setbacks, and periods are more or less intermixed throughout the town and the characteristics of vertical construction alone could not define plan units in Beyarmudu. The main urban land utilization areas were demarcated based on land use of parcels and period of development. According to this, commercial premise locates at the southern part of the town along the main street. Public facilities take place along the commercial districts on eastern part of the town, whereas the rest of the town has residential uses.

The Genetic Plan Units in Figure 2 were then delineated by compiling all the aforementioned data first as individual layers and the analysis in its compound forms. Ultimately a synthesis, the genetic plan units which were discovered via this process are;

The pre-colonial residential primary similar house forms by elevation and setback on similar size parcels within the traditional town centre and facing on the main street.

The pre-colonial residential unit - house forms on parcels situated on connecting roads around the strips of pre-colonial residential primary and multipurpose main street early. Between and around the traditional core is mostly generational subdivision of the first settlers' lands and buildings. Town square next to the mosque in the town creates first urban nuclei.

Morphology of Town; as seen on figure 2 first urban settlement located very close to south border with the extension on east to west. After the conflict in Cyprus especially after the international border town has been developed on south to north axis along the main street. The town square located in first urban nuclei attached on the main street. Other morphological area development filled gaps in this pattern and fourth order continued the amorphous parcel patterns into green fields. The result of post conflict and new urban development is somewhat sprawling in shape and space, away from the town centre but ultimately confined by the fixation line of the international border on south and agricultural land on north. The last morphological development is the two-story villa development is only slightly less amorphous because it is happening along geometrically planned roads within the confinement of the border.

Both connectivity and compactness values of Beyarmudu support the sprawl denoted by the morphological maps. As the town expands towards the northern agricultural lands, the visual obstacles tend to disappear. This visual transparency along with high connectivity values enables a second centre within the system that can be converted to public use. Circularity values on the other hand, emphasize the main street as the commercial and public facility functions located here have high visibility levels. Although local integration around this area shows segregation from the system, the linearity of the pattern is reinforced with a shift towards the centre of the system, denoting the mix use facilities of newer periods. 


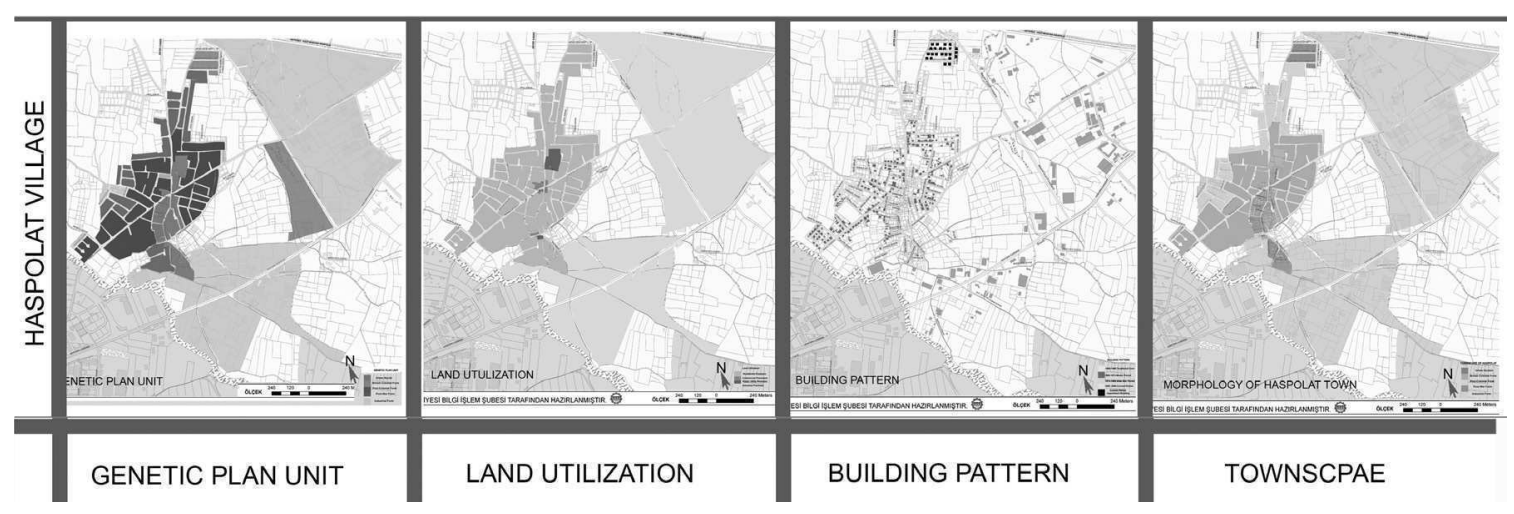

Figure 3

Haspolat. Building pattern.

Haspolat:

Building Pattern; In Haspolat, Figure 3 distinguishes the buildings based on period of construction and architectural styles with colonial and post-war buildings being grouped as one. The periods were determined based on material, elevation, and setback from street like Beyarmudu. Some buildings also helped with period placement by displaying buildings dates on their front façades.

Buildings before 1958 have significance with their façade and their window and door ratios, which signify them from other periods. For example, those built with adobe, a material mostly used pre-conflict, are typically at grade with 20 percent built at the street edge and 80 percent built within one meter of the street. Analysis shows that more than half of the reinforced concrete buildings have setbacks of 3 to 4 meters placing their construction after 1958. The building pattern after colonial period has setbacks from the street line about 3-4 m. with balcony at the front façade. Shading devices on the front façade on the balcony is the main significant element from the street. This aligns with the dating of most concrete construction just before the post-war. After the post war few buildings has been constructed.

The main urban land utilization areas were demarcated based on land use of parcels and period of development. Haspolat has two commercial uses; the one has been located at the eastern part of the town which was developed parallel to the border. But today it loses its character and new commercial premises has been shifted towards the intersection of the two main streets as seen in figure 3, Public facilities take its place along the commercial districts on northern part of the town. Addition to this industrial district has been developed western part of the town along the border and later on, it has been sprawled until the main street. The residential premises have been developed towards the northern part of the town.

First urban nuclei have developed on the eastern part of the town as called traditional plan unit. British Colonial plan unit has been developed along the eastern and western axis of the town. Thirdly Post-colonial units have been developed the surrounding of the British colonial plan unit. During the post-war, new plan unit that called post-war plan unit has been developed towards the northern part of the town away from the border.

Morphology of Town; as seen on figure 3, first urban settlement located very close to south border with the extension of west. During the post-war in Cyprus especially after the buffer zone town has been developed on north axis the intersection of the two-matrix route. The town square located on the traditional core and all commercial and public activities are within the traditional core. While the first urban nuclei have been located in the east, the post-war morphological form shifted to the east and traditional core has been shift there. British Colonial morphologic area has been observed surrounding of the traditional character area towards south to north, but after the war new morphological character has been developed along the northern part of the town. The other morphological area development filled gaps. New industrial morphological form has been 
observed at the eastern part of the town with industrial building pattern, current building pattern and industrial land use function. The result of post-war directly affects the morphology of town by the means of plan unit, land use and building pattern. The centre has been shifted towards the eastern part and it has been transformed to a different morphology.

Compactness values of Haspolat present the new residential development towards the northern sections support as denoted by the morphological maps. The town experiences a fringy expansion towards the north and southeast. The northern development creates a secondary centre with the highest compactness values, and less visual obstacles. Circularity values on the other hand, emphasize the triple centrality of the western zone divided by the main street. This zone dating back to modern period presents high local integration and connectivity values independent from functional uses. Having high visibility levels and relatively high integration levels supports the fringy development of Haspolat.

\section{Results and discussion}

As a part of an ongoing research, this study has presented that morphological and syntactic analyses executed on urban scale supports data acquired from different methods. The development of two towns interrupted by a border presents different outcomes. As Beyarmudu continues to develop in a linear manner towards north and therefore its urban nucleus gets deeper in the system, Haspolat develops centrally with unequal fringes.
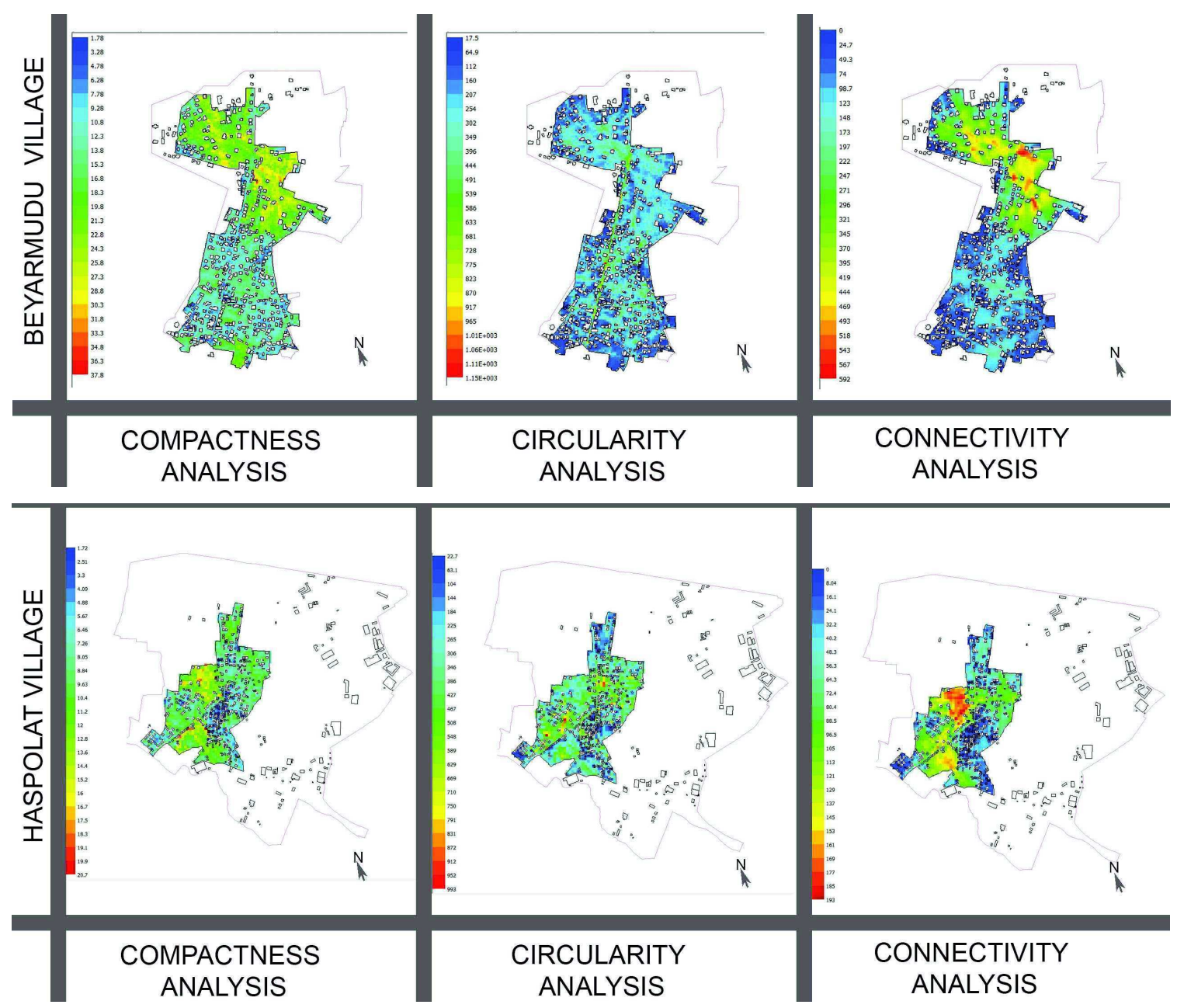

Figure 5

Beyarmudu and Haspolat compactness, circularity and connectivity analysis 
Although northern development creates a secondary centre, Beyarmudu still maintains the main street idea within its linear pattern. However, the vast expansion seen in Haspolat pattern supports sub centre developments which is a hint that the town may expand even further in the coming years.

The human interface on the other hand is not examined in this paper, especially the functional uses, mobility in streets and visual access aspects are among the important data that are needed to be searched.

\section{Conclusion}

This study, having explored urban morphology based on historico-geographical approach and syntactic approach; This comparative study suggest that the morphological and syntactic analysis can correlate to each other for finding a better reliable outcomes of the development of city. In this paper, the study of morphological characteristics of the two frontier villages in Northern Cyprus has been analysed.

From a more general perspective, at the end of this study, it is also hoped that the proposed analysis method on urban morphology shaped by morphological and syntactic approaches will help designers, planners, cultural geographers and urban morphologists and architects to find better solutions while they are designing, analysing, planning and/or conserving existing - historic and traditionalurban areas in town and cities also it draws the development strategies for the towns.

\section{References}

Baker, N. J., Slater, T. R., 1992, Morphological regions in English medieval towns, in: Larkham, P. J., Whitehand, J. W. R. (eds.), Urban landscapes, international perspectives, Routledge, London.

Barrett, H. J., (1996), Townscape change and local planning management in city centre conservation areas, Unpublished $\mathrm{PhD}$ thesis, University of Birmingham.

Batty, M. (2001), Exploring Isovist Fields: Space and Shape in Architectural and Urban
Morphology, Environment and Planning B: Planning and Design 2001, volume 28, pages $123-150$.

Benedikt, M. (1979) To Take the Hold of Space: Isovists and Isovist Fields, Environment and Planning B: Planning and Design, 6, p. 4765

Cullen, G., (1961), The Concise Townscape, Architectural Press,USA

Conzen M.R.G. (1988), Morphogenesis, morphological regions and secular human agency in the historic townscape as exemplified by Ludlow, in Denecke,D. and Shaw,G.(eds) urban historical geography, (Cambridge Uni. Press, Cambridge) pp. 253-272.

Conzen, M. R. G., (2004) 'Morphogenesis and structure of the historic townscape in Britain', in: Thinking about Urban Form: Papers on Urban Morphology, 1932-1998, Peter Lang London.

Conzen, M.R.G., (1975), Geography and Townscape Conservation, H. Uhlig, C. Lienau (Eds.), Anglo-German Symposium in Applied Geography, GiessenWürzburgMünchen, Lenz, Giessen, pp.95-102.

Hillier, B., Leaman, A. (1974), how is Design Possible?. Journal of Architectural Research and Teaching, 3, 4-11.

Hillier, B., Burdett, R., Peponis, J., Penn, A. (1987), Creating Life: or, Does Architecture Determine Anything. Architecture and Behaviour, 3(3), 233-250.

Jones, A., (1991). The management of residential townscapes, Unpublished $\mathrm{PhD}$ thesis, University of Birmingham.

Moudon A.V., 1997, Urban morphology as an emerging interdisciplinary field, Urban morphology, V1, Heron press, Birmingham U.K, 3-10

Olveira V., (2016), Urban Morphology, an Introduction to the Study of the Physical Form of Cities, Springer Publication.

Smailes, A.E (1995), The Geography of Towns, London, Hutchinson

Whitehand, J. W. R., (2012), Issues in Urban Morphology, Journal of urban morphology V.16 (1), , University of Birmingham, pp5565

Whitehand, J. W. R et.al. (2011), Urban morphology and conservation in China, 
Cities, V28(2),Elsevier

Whitehand, J. W. R., (1989), Residential development under restraint: a case study in London's rural-urban fringe, School of Geography, Occasional Publication number 28 , University of Birmingham. 